\title{
Ayurveda Aetiology, Pathogenesis \& Holistic Management of Inflammatory Bowel Disease
}

\author{
Nishant Shukla* \\ Head of Kayachikitsa (Ayurved medicine), Gujarat Ayurved University, India
}

Submission: August 09, 2018; Published: September 17, 2018

"Corresponding author: Nishant Shukla, Professor \& Head of Kayachikitsa (Ayurved medicine), Shri V. M. Mehta Ayurveda College, Anandpar Rajkot, Ex. Head of Kayachikitsa Gulabkunverba Ayurved Mahavidyalaya, Anil 3 Patel Colony, Jamnagar, India, Tel: +91-9426984260;

Email: nishantvd@rediffmail.com

Keywords: Inflammation; Colon; Large intestine; Abdominal pain; Diarrhoeal disease

\section{Introduction}

Diarrhoeal disease with inflammation of colon or large intestine present with abdominal pain discomfort, passing of liquid stools with mucus, blood or bleeding were observed in ulcerative colitis, Crohn's disease, etc. pathogenesis of large intestine was grouped as Inflammatory bowel disease. The disease was believed to be occurring due to indulgence of unwholesome food and routines. Mythological texts narrate that the diarrhoeal disease first occurred after demolition of Daksha Yagyna due to indulgence of beef, alcoholic beverages, other unwholesome food, routines and Shiva Kopa (stress induced). The disease has been narrated in ancient scientific texts i.e. Vedas. Ancient ayurvedic texts Charaka Samhita (1500 BC) and Acharya Sushruta (1200 BC) narrated the disease in Chikitsa Sthana (sections dealing with medical management of diseases) and Uttar Tantra (section dealing with management of disease with other then surgical management) respectively [1].

Both the Ayurveda texts narrates that Agni (digestion, metabolism \& assimilation function) gets hampered first due to indulgence of etiological factors, infections, etc. As a general rule of Ayurveda pathogenesis Astang Sangraha (6th century AD) narrates that all the diseases occur due to improper functions of Agni especially the disorders of abdomen \& specifically ascites. The disease in early twentieth century believed to be psychosomatic that later on classified as immune mediated inflammatory condition; the study of psychosomatic relationship in various disease has been studied all across the globe and as per present understanding immune system has great deal of relation with psyche of a person that may precipitate or propagate morbid condition of varying morbidity from simple inflammation to grave disease like cancer, diabetes, ulcerative colitis, etc. [2].
Incidence of the disease was as old as human civilization; ancient indian mythological texts narrates that the disease was first seen after demolition of Daksha Yagya due to stress and indulgence of beef and other food irregularities along with Jwara (pyrexia disease). Disease has been described in Vedas; ancient Ayurveda texts Charaka Samhita (1500 BC) and Sushruta Samhita (1200BC) has narrated the all diarrhoeal disease in details i.e. aetiology, pathogenesis, pathological changes, therapeutic management including purification process.

Diarrheal disease, like other abdominal disease occurs due to derangement of Agni (altered digestion, metabolism, assimilation); Agni regulates all the biotransformation within the body, strength, host defence mechanism, longevity, complexion, nourishment, etc. Agni is the concept narrated in ancient ayurvedic classics that may be correlated with enzymes $\&$ hormones. Other body humour vitiated in the disease was Vata; Vata regulates all types of transformation \& movements within the body. Fluids from different parts of the body get into the colon that leads to inflammation of colon that leads to passing of watery stools - increased frequency of stool. Dietetic indiscretion \& contaminated food \& beverages, Krimi (helminth's \& pathogen), unwholesome food \& beverages and mental stress cause vitiation of Vata, Agni, Pitta, and other body fluids.

The indulgence of these factors produces vitiation of Agni - gastric digestion; Agni governs all digestive functions; indigestion of food results in inflammation in colon, vitiation of Agni \& indulgence of aetiological factors produces vitiation of Vayu; the vitiated Vayu draws body fluids (from all parts of the body) to colon. Body fluids collection in colon results in typical symptom of diarrhoeal disease i.e. increased frequency of stool and passing of liquid stools. Bhayatisara and Shokatisara were 
the two diarrhoeal diseases that occur due to psychological stress. In early twentieth century the disease was considered as psychosomatic disease, but now a day these diseases have been reclassified as inflammatory bowel disease. Acharya Sushruta narrated that psychological stress \& dietetic indiscretion leads to changes in Agni \& host defence mechanism - the leads to inflammation in part of colon - these inflammation leads to ulceration in part of colon and lastly presents with passage of increased frequency of stool with blood, pus or both or passage of only blood along with another constitutional symptom.

Standardised protocol of treatment narrated in ancient ayurvedic classics were controlling primary symptoms \& signs of disease second objectives were improve digestion \& metabolism, complete remission \& resolution of disease by reverting pathogenesis. Ancient Ayurveda texts narrated that disease ought to be treated as per the condition of disease i.e. Sama \& Nirama. In the first stage of disease also known as Sama Avastha medicaments that improve digestion were to be used and stopping diarrhoea at once. Once the function of Agni gets regularised and Vata gets normalised the drugs having antidiarrhoeal properties like Kutaj (H. antidysentrica) etc. may be used. In severe cases Basti rectal administration of decoction made of Mocha Rasa.

Herbal formulation commonly used by for treating the medical condition was a combination of Shatavari (A. racemose) 1 gms, Yastimadhu (G. glabra) 1 gms, Dhatriloha (ayurvedic formulation - used for clinical practice since $13^{\text {th }}$ century AD) 250mg, Kutaj (H. antidysenterica) 1 gms, Vrudha Gangadhara Churna (ayurvedic formulation - used for clinical practice for more than 5 centuries) 1 gms, and Panchamruta Parpati (ayurvedic formulation - used for clinical practice for more than 5 centuries) $125 \mathrm{mg}$ three times a day with honey along with Shankhavati 1 tablet after meals. Patient were advised reduce irritant food with restriction of aerated beverages, sour materials, bakery items, packaged foods, pre - cooked foods, etc. patient were advised to use ginger juice twice a day before meals. Patients having complaints of severe bleeding ( $\mathrm{Hb}<9 \mathrm{gm} /$ $\mathrm{dl}$ or profuse bleeding) were given ayurvedic homeostatic were given. Patients were advised to follow diet easily digestible diet for regular bowel movements.

As per the clinical data of 30 patient managed by the author of inflammatory bowel disease marked improvement was observed in patient treated with these medicines. Patient that were managed by steroids or sazo were advised to gradually taper the dosage with these Ayurveda management; no altered responses were observed after restricting or discontinuing sazo. Bleeding, frequency of stools, pus, abdominal pain \& abdominal discomfort were relieved in all patients. Other constitutional symptoms like abdominal pain, discomfort, malaise was relieved completely. Over and above the cardinal signs \& symptoms of the disease digestion, metabolism, sleep \& awakening schedules, and wellbeing of the patient was improved. Patient were advised to follow the seasonal routine related to food and use seasonal fruits \& vegetable and modest reduction in quantity of food. No relapse has been observed within a year after treatment.

\section{References}

1. Ancient Ayurveda text Astang Sangraha Nidan section (Nidan Sthana). (Chapter 12), (Udar Roga), Stanza 1.

2. Ancient Ayurveda text Sushruta Samhita Uttar Tanatra. (Chapter 40), Stanza $13 \& 14$.

\section{Your next submission with JuniperPublishers will reach you the below assets}

- Quality Editorial service

- Swift Peer Review

- Reprints availability

- E-prints Service

- Manuscript Podcast for convenient understanding

- Global attainment for your research

- Manuscript accessibility in different formats

( Pdf, E-pub, Full Text, audio)

- Unceasing customer service

Track the below URL for one-step submission

https://juniperpublishers.com/online-submission.php 